\title{
Nephrotoxicity of Bence-Jones proteins: interference in renal epithelial cell acidification
}

\author{
A.L. Nicastri1, \\ M.J.B.A. Prado², \\ W.V. Dominguez ${ }^{2}$ \\ and E.B.A. Prado ${ }^{2}$
}

\author{
${ }^{1}$ Departamento de Biologia Celular, U niversidade Federal do Paraná, \\ Curitiba, PR, Brasil \\ 'Laboratório de Fisiopatologia Renal, Hospital das Clínicas, \\ Faculdade de Medicina, U niversidade de São Paulo, São Paulo, SP, Brasil
}

\begin{abstract}
\section{Correspondence}

A.L. Nicastri

Departamento de Biologia Celular

Universidade Federal do Paraná

80060-000 Curitiba, PR

Brasil

Publication supported by FAPESP.

Received June 8, 2001

Accepted January 15, 2002

The aim of the present study was to evaluate the acidification of the endosome-lysosome system of renal epithelial cells after endocytosis of two human immunoglobulin lambda light chains (Bence-Jones proteins, BJP) obtained from patients with multiple myeloma. Renal epithelial cell handling of two BJP (neutral and acidic BJP) was evaluated by rhodamine fluorescence. Renal cells (MDCK) were maintained in culture and, when confluent, were incubated with rhodamine-labeled BJP for different periods of time. Photos were obtained with a fluorescence microscope (Axiolab-Zeiss). Labeling density was determined on slides with a densitometer (Shimadzu Dual-Wavelength Flying-Spot Scanner CS9000). Endocytosis of neutral and acidic BJP was correlated with acidic intracellular compartment distribution using acridine orange labeling. We compared the pattern of distribution after incubation of native neutral and acidic BJP and after complete deglycosylation of BJP by periodate oxidation. The subsequent alteration of $\mathrm{pI}$ converted neutral BJP to acidic BJP. There was a significant accumulation of neutral BJP in endocytic structures, reduced lysosomal acidification, and a diffuse pattern of acidification. This pattern was reversed after total deglycosylation and subsequent alteration of the $\mathrm{pI}$ to an acidic BJP. We conclude that the physicochemical characteristics of BJP interfere with intracellular acidification, possibly explaining the strong nephrotoxicity of neutral BJP. Lysosomal acidification is fundamental for adequate protein processing and catabolism.
\end{abstract}

Renal handling of monoclonal immunoglobulin light chains, Bence-Jones proteins (BJP), is an important aspect of multiple myeloma. Clinical and experimental studies have been conducted to elucidate the mechanisms related to protein overload (1) that lead to aminoaciduria and glycosuria $(2,3)$, acidification defects and tubular cast formation (4).

The main organs involved in the removal of BJP from the circulation are liver and kidney (5). Many investigators have studied
Key words

- Bence-Jones proteins

- Renal cell acidification

- Endocytosis

- Lambda light chain protein

...................... how protein handling by renal cells leads to disease but few studies are available about the sugar content and other physicochemical characteristics of these proteins.

The aim of the present study was to correlate sugar content and BJP isoelectric point (pI) to endocytosis and intracellular acidification. Some studies have indicated the importance of the $\mathrm{pI}$ of light chains, since a $\mathrm{pI}$ higher than 6.0 is more frequently associated with renal damage (6). 
BJP was labeled with rhodamine by the method of Maxfield et al. (7) and sugar content was removed by the method of Spiro (8). After deglycosylation, the samples were submitted to SDS polyacrylamide electrophoresis, isoelectric focusing and quantification by amino acid analysis.

MDCK cells were grown on coverslips on Petri dishes containing Dulbecco's modified Eagle's medium (DMEM) (9). Twentyfour hours before the experiment, confluent cells were incubated with DMEM without calf serum.

Cells were incubated with $40 \mu \mathrm{g}$ of BJP dissolved in $1 \mathrm{ml}$ DMEM without calf serum for 1, 30 and $60 \mathrm{~min}$. The medium was then discarded, and cells were washed with $0.9 \%$ saline solution and fixed with $1 \%$ glutaraldehyde solution in phosphate buffer, $\mathrm{pH}$ 7.2, for $20 \mathrm{~min}$. Slides were covered with coverslips and observed under the microscope.

Endocytosis was quantified by densitometry $(525 \mathrm{~nm})$ of the film and area units were integrated by the densitometer (Shimadzu Dual-Wavelength Flying-Spot Scanner CS9000, Tokyo, Japan). The cellular area was measured on photographs using an image analysis processor system (MINIMOP, Kontron Bildanalyser, Kontron Elektronic Group, Eching, Munich, Germany). Intracellular uptake of BJP is reported as densitometer unit per cellular area.

Acidic compartments were identified after endocytosis of native and deglycosylated BJP by incubation with acridine orange for 60 min. Cells not incubated with BJP were used as controls.

Cells were observed without fixation in glutaraldehyde. Coverslips were mounted on glass slides and observed by fluorescence microscopy (Axiophot, Zeiss, Oberkochen, Germany). The intensity and range of orange color are proportional to acidity, and neutral structures are green.

Living cells took up acridine orange readily. In all cells, the nuclei were stained bright green, yellow-green or yellow (de- pending on the concentration of the dye).

Results were analyzed with the Sigma Plot 5.0 software (Sigma-Stat Statistical Analysis System version 1.01, Scientific Graph System, Jandel Scientific, Chicago, IL, USA) using the nonparametric KruskalWallis and Mann-Whitney tests. Results are reported as median and $25-75 \%$ percentiles. The level of significance adopted was 0.05 .

Labeling of neutral BJP chains was significantly more extensive with rhodamine than labeling of acidic BJP. At 1, 30 and 60 min, the absorbance values [median and percentiles (25-75\%)] were 794 (752-1159), 1055 (957-1135) and 1444 (1067-1082) for neutral BJP and 479 (248-652), 681 (584830 ) and 655 (432-783) for acidic BJP, respectively.

Marked vacuolation was found after 30 min of incubation with neutral BJP, but not after incubation with acidic BJP. After 60 min of incubation with neutral BJP we could observe a reduction of cellular volume and a significant retention of protein (Figure 1A) in comparison with acidic BJP (Figure 1B).

Living cells incubated with acridine orange showed a modified pattern of acidic lysosome-endosome structures after incubation with neutral BJP (Figure 1C). This pattern was reversed after $\mathrm{pI}$ alteration of neutral BJP. On the other hand, a normal pattern of acidification was observed after incubation with acidic BJP, with perinuclear localization of lysosomes. Figure 2 illustrates the catabolism of acidic BJP in spite of a progressive accumulation of neutral BJP.

Our laboratory has reported the nephrotoxicity of BJP in acute and chronic models $(10,11)$. On the basis of the present results, we conclude that $\mathrm{pI}$ modulates cytotoxicity by mechanisms related to internalization and intracellular directioning and catabolism. This pattern was reversed after alteration of the physicochemical properties of BJP. These data are in agreement with those reported by others who showed a relation between nephrotoxicity and $\mathrm{pI}(12,13)$. 
The new contribution of the present study was the correlation between physicochemical characteristics of BJP and nephrotoxicity according to different patterns of uptake and intracellular processing, the direct correla-
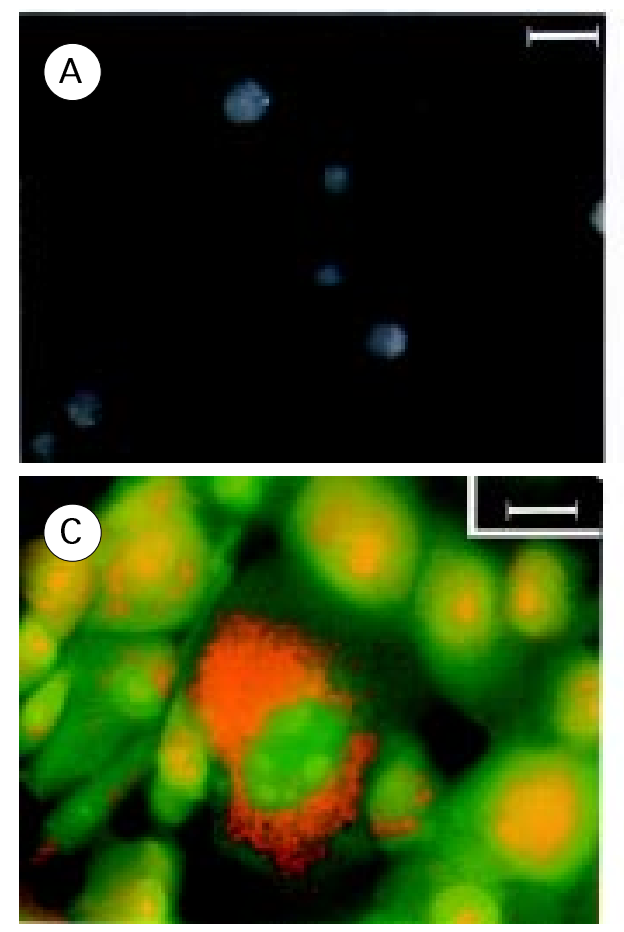

tion with lysosomal acidification and consequent intracellular digestion, and the importance of carbohydrate content, amino acid composition and $\mathrm{pI}$ before and after metaperiodate oxidation.
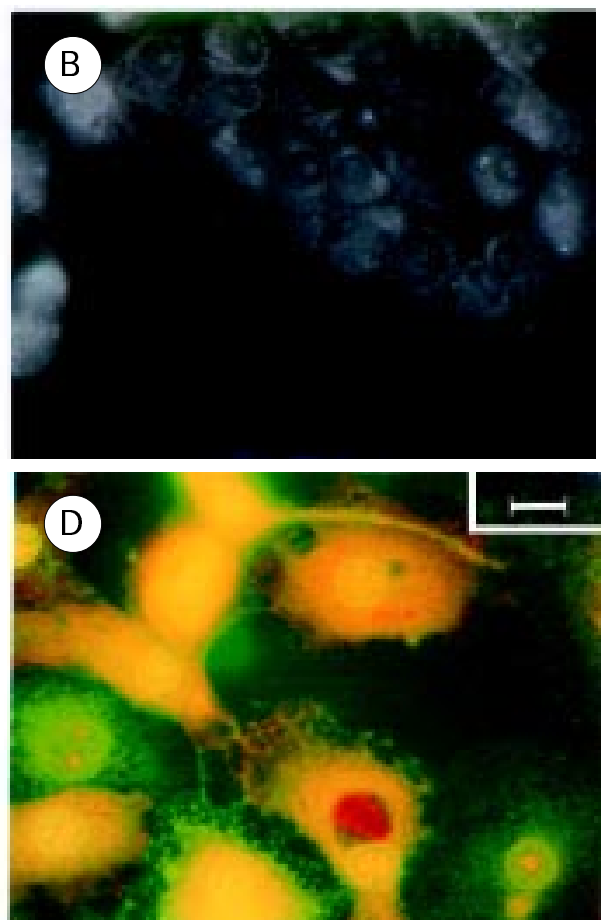

Figure 1. Intracellular uptake of rhodamine-labeled Bence-J ones proteins (BJ P) by MDCK cells and patterns of acidification with acridine orange. A, MDCK cells after 60 min of incubation with neutral BJ P labeled with rhodamine. $B$, MDCK cells after 60 min of incubation with acidic BJ P labeled with rhodamine. C, MDCK cells after incubation for 30 min with neutral BJ P and acridine orange. D, MDCK cells after incubation for 30 min with acidic $\mathrm{BJ} \mathrm{P}$ and acridine orange. Bars $=5 \mu \mathrm{m}$.

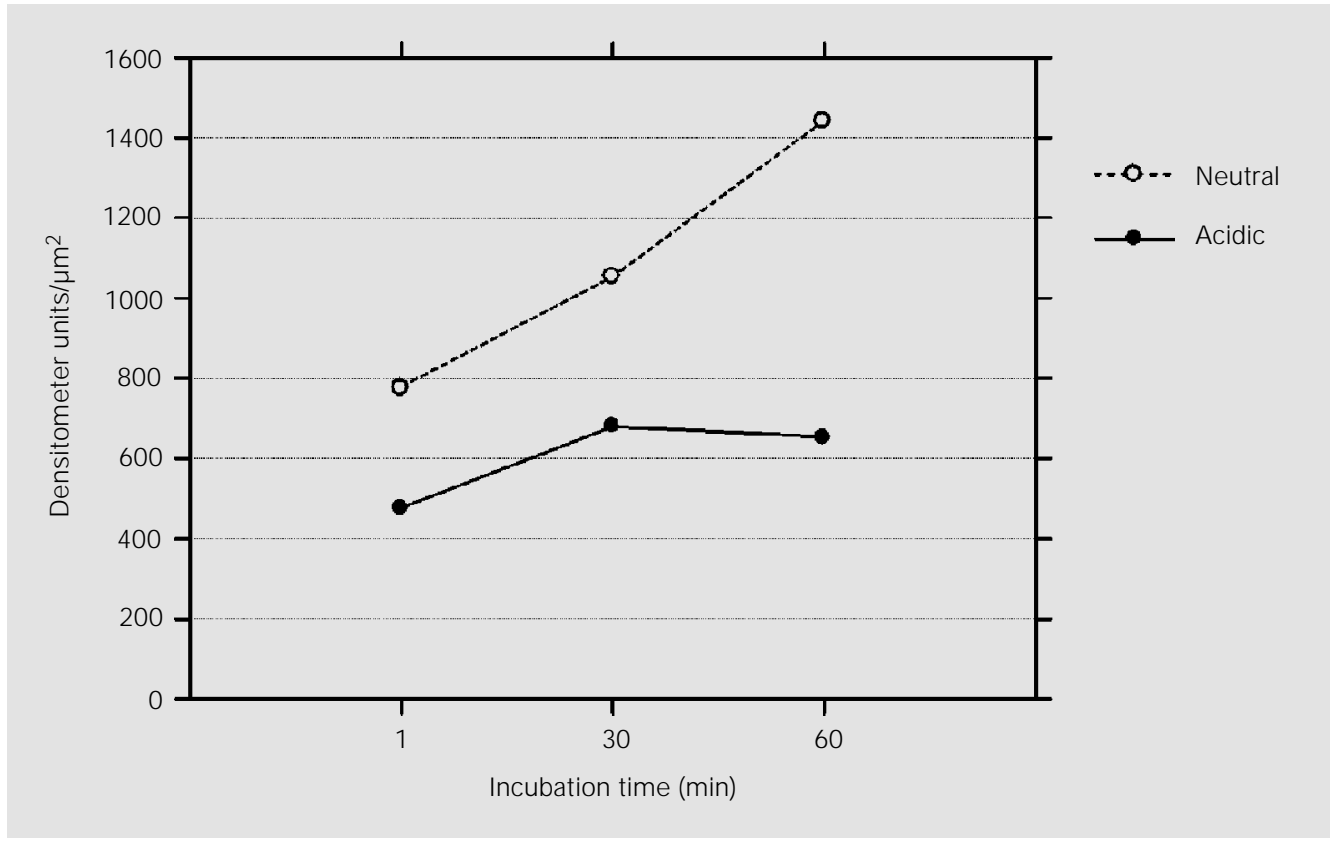

Figure 2. Intracellular uptake of rhodamine-labeled BenceJ ones proteins (BJ P). The cellular uptake of rhodamine-labeled BJ P was observed after 1,30 and 60 min of incubation and is reported as densitometer unit per cellular area. 


\section{References}

1. Prado EBA, Prado MJBA \& Nicastri AL (1992). Nefropatia associada a paraproteínas. In: J enner C (Editor), Atualidades em Nefrologia II. Sanvier, São Paulo, Brazil, 71-78.

2. Lazer GS \& Feiten DI (1981). Distal renal tubular acidosis in multiple myeloma. Archives of Internal Medicine, 141: 655-657.

3. Short IA \& Smith J P (1959). Myelomatosis associated with glycosuria and aminoaciduria. Scottish Medical J ournal, 4: 89-93.

4. Pasquali $\mathrm{S}$, Zucchelli $\mathrm{P}$, Casanova $\mathrm{S}$, Cagnoli L, Confalonieri R, Pozzi C, Banfi G, Lupo A \& Bertani T (1987). Renal histological lesions and clinical syndromes in multiple myeloma. Clinical Nephrology, 27: 223-228.

5. Prado MJ BA, Nicastri AL, Costa PLA, Rockman T, Tersariol IL, Nader HB, Barros RT \& Prado EBA (1997). The renal and hepatic distribution of Bence-J ones proteins depends on glycosylation: a scintigraphic study in rats. Brazilian J ournal of Medical and Biological Research, 30: 865-
872.

6. Melcion $C$, Mougenot $B$, Baudoin $B$, Ronco $P$, Moulonguet-Doleris $L$, Vanhille $\mathrm{PH}$, Beaufills $M$, Morel-Maroger $L$, Verroust $P \&$ Richet $G$ (1984). Renal failure in myeloma: relationship with isoelectric point of immunoglobulin light-chains. Clinical Nephrology, 22: 138-143.

7. Maxfield FR, Schlessinger J, Shechter $Y$, Pastan I \& Willingham MC (1978). Collection of insulin, EGF and alpha2-macroglobulin in the same patches on the surface of cultural fibroblasts and common internalization. Cell, 14: 805-810.

8. Spiro RG (1966). Characterization of carbohydrate units of glycoproteins. Methods in Enzymology, 8: 26-52.

9. Nicastri AL (1993). Influência de características físico-químicas na captação e processamento intracelular de proteínas de Bence J ones humanas por células epiteliais renais. Estudo experimental. Doctoral thesis, Instituto de Ciências Biomédicas, Universidade de São Paulo, São Paulo, SP, Brazil.
10. Prado $M J B A$, Nicastri $A L$, Leo $P$, Uchino E, Sesso A, Marcondes $M \&$ Prado EBA (1993). Nephrotoxicity of human Bence J ones protein in rats: proteinuria and enzymuria profile. Brazilian J ournal of Medical and Biological Research, 26: 633638.

11. Nicastri AL, Prado MJBA, Sesso A \& Prado EBA (1998). Defective proximal tubule lysosomal acidification by Bence J ones protein: an immunoelectron microscopy study. Experimental Nephrology, 6: 514-521.

12. Weiss JH, Williams RH, Galla J M, Gottschall J L, Rees ED, Bathena D \& Luke RG (1981). Pathophysiology of acute BenceJ ones protein nephrotoxicity in rat. Kidney International, 20: 198-210.

13. Diemert MC, Musset L, Gaillard O, Escolano S, Baumelou A, Rousselet F \& Galli J (1994). Electrophoretic study of the physico-chemical characteristics of Bence$J$ ones proteinuria and its association with kidney damage. J ournal of Clinical Pathology, 47: 1090-1095. 